\title{
Oral Administration of Agaricus blazei (H1 Strain) Inhibited Tumor Growth in a Sarcoma 180 Inoculation Model
}

\author{
Yun-Lyul LEE 1), Heui-J in KIM2), Mi-Sook LEE 3), J i-Min KIM4), J in-Soo HAN5), \\ Euk-Ki HONG6), Myung-Sang KWON7), and Min-J ae LEE ${ }^{8)}$
}

\begin{abstract}
1)Department of Physiology, College of Medicine, Hallym University, Chunchun, ${ }^{2) D e p a r t m e n t ~ o f ~}$ Laboratory Animal Science, College of Medicine, Seoul National University, Seoul, ${ }^{3}$ Department of Pathology, College of Medicine, Seoul National University, Seoul, ${ }^{4}$ Yuhan Research Center, Yuhan Corporation, Anyang, Kyunggido, ${ }^{5}$ Breeding Center/Hoe-Eun Life Science Research Institute, Gyeongigi-Do, ${ }^{6}$ Department of Laboratory Environmental and Biological Engineering, College of Eengineering, ${ }^{7}$ Department of Veterinary Medicine, College of Animal Resources Science, Kangwon National University, Chunchun, and ${ }^{8)}$ Department of Laboratory Animal Research, Samsung Biomedical Research Institute, Seoul, Korea
\end{abstract}

\begin{abstract}
Agaricus blazei (H1 strain) was tested for its anticancer activity using a sarcoma 180 (S180) inoculation model and the changing patterns of splenocyte subsets were examined. Its hot-water extract was administered orally to ICR and KSN nude mice that were inoculated with $\mathbf{S 1 8 0}$. The growth of $\mathbf{S 1 8 0}$ was significantly inhibited in A.blazei treated groups. Pan $T$ cells significantly increased in all treated groups compared to controls, even in KSN nude mice. Splenocyte subset changes were slightly different between ICR and KSN nude mice. This $S 180$ inoculation model proved to be effective in screening the antitumor effect of basidiomycetes and allowed comparisons of immunological cellular changes between the mouse strains.
\end{abstract}

Key words: Agaricus blazei, antitumor effect, FACS, sarcoma 180 (S180)

\section{Introduction}

Agaricus blazei, a novel edible mushroom, has been used as a treatment for a long time by cancer patients, and has also been reported to have antimutagenic, bactericidal [1], and antitumor effects [2]. Its antitumor effect seems to be due to the restoration or augmentation of immunological responsiveness and to the potentiation of host-defense systems through cellular immunity [3-6].

Sarcoma 180 (S180) is a mouse-originated tumor and one of the most frequently used cell lines in antitu- mor related research in vivo [4,7]. It has also been reported that polysaccharides from basidiomycetes strongly inhibit the growth of S180 implanted subcutaneously in mice by stimulating the defense mechanisms of the host [2].

To date, related studies on A. blazei have mainly involved chemical analyses [8-10]. Parenteral administration has usually been adopted in the S180 inoculation model to study the in vivo effects of natural products, including A. blazei [11]. Using information derived from these previous studies, we studied the antitumor effects of oral administration of A. blazei using 
an in vivo model and detailed splenic subset changes were examined on the basis of clinical trials.

\section{Materials and Methods}

Preparation of hot-water extract of Agaricus blazei (HI strain)

Hot-water extracts of A. blazei (H1 strain) were obtained from the Laboratory of Environmental and Biological Engineering, Kangwon National University, and treated as follows: dried A. blazei was blended and the resultant powder was extracted with distilled water at $90^{\circ} \mathrm{C}$ for $12 \mathrm{~h}$. After filtering insoluble residue through Advantec filter \#2, the resultant solution was precipitated by adding 3 volumes of cold ethanol. The precipitate was dissolved in water and dialyzed for 2 days. The brown powder acquired from the freezedried supernatant was used for the study.

\section{Tumor}

Sarcoma 180 (S180) was supplied by the Korea Cell Line Bank (KCLB), Cancer Research Institute, Seoul, Korea, and maintained by intraperitoneal passages in ICR mice $\left(5 \times 10^{6}\right.$ cells/head $)$; purchased from Biogenetics, Korea in vivo.

\section{Sulforhodamine (SRB) Assay}

After allotting S180 at $5 \times 10^{3}$ cells/well in $180 \mu \mathrm{l}$, A.blaze $i$ was added at $20 \mu \mathrm{l} /$ well in the concentrations shown in Table 1, and incubated for $48 \mathrm{~h}$. The supernatant was aspirated, fixed in cold $50 \%$ trichloroacetic acid (TCA) solution $\left(50 \mu \mathrm{l} /\right.$ well) at $4^{\circ} \mathrm{C}$ for $1 \mathrm{~h}$, and then dried. After staining with $0.4 \%$ SRB solution, in $1 \%$ acetic acid $(100 \mu \mathrm{l})$ for $30 \mathrm{~min}$, the optical density (OD) value was measured at $540 \mathrm{~nm}$.

\section{S180 Inoculation Modeling}

Five-week-old male ICR and athymic KSN nude mice were purchased from SLC Inc., Japan. All mice in this study were inoculated with S180 in the dorsal area (s.c. $1 \times 10^{5}$ cells/mouse), and after 7 days (day 0 ) the mice with cancers of over $5 \mathrm{~mm}$ in diameter were divided into 3 groups to form similar average groups with respect to tumor size. Each group of mice of each strain was orally administered A. blazei daily as follows: 0 $\mathrm{mg} / \mathrm{kg}$ (control), $100 \mathrm{mg} / \mathrm{kg}$, and $300 \mathrm{mg} / \mathrm{kg}$ in normal saline. Body weights and feed consumption were re-
Table 1. The tumor growth inhibition rate by A. blazei hotwater extract

\begin{tabular}{cccc}
\hline $\begin{array}{c}\text { A. blazei } \\
\text { conc. }\end{array}$ & $5 \times 10^{5}$ & $\begin{array}{c}\text { Sarcoma } 180 \\
1 \times 10^{6}\end{array}$ & $1 \times 10^{7}$ \\
\hline Control (0) & - & - & - \\
3 & 3.6 & 3.9 & 2.4 \\
10 & 4.4 & 3.2 & 2.8 \\
30 & 9.2 & 10.8 & 7.3 \\
100 & 17.3 & 19.3 & 14.0 \\
1,000 & 32.0 & 30.5 & 26.3 \\
\hline
\end{tabular}

The cell concentration was $5 \times 10^{5}, 1 \times 10^{6}, 1 \times 10^{7} /$ well, and the values ( $n=6 /$ group/assay).

corded on each day. On days 10,17 , and 24 , six mice per group were sacrificed by cervical dislocation, and then organs and tumors were removed, weighed, and used for flow cytometry.

\section{Assay of Antitumor Activity}

The tumor diameter was measured using calipers on each day. Tumor volume and percent inhibition were determined using the following formulae [11]: Tumor volume $\left(\mathrm{cm}^{3}\right)=4 / 3 \pi\left(\mathrm{a}^{2} \mathrm{~b}\right) / 2$, where $\mathrm{a}$ is the short diameter $\left(\mathrm{mm}^{2}\right)$ and $\mathrm{b}$ is the long diameter $\left(\mathrm{mm}^{2}\right)$; Inhibition of cancer $(\%)=(1-\mathrm{T} / \mathrm{C}) \times 100 \%$, where $\mathrm{T}$ is the mean for the treated groups and $\mathrm{C}$ is the mean of the controls.

\section{Analyses of Splenic Lymphocytes Subsets}

All six spleens from each group were passed through a stainless steel mesh, and then red blood cells (RBCs) were lysed. After washing with Hanks' balanced salt solution $($ HBSS $)$ three times, splenocytes $\left(1 \times 10^{6} / \mathrm{ml}\right)$ were suspended in Roswell Park Memorial Institute(RPMI)-1640 with $10 \%$ fetal bovine serum (FBS), and dually stained on ice for $30 \mathrm{~min}$ with each monoclonal antibody $(\mathrm{mAb})$. After washing three times, the cells were suspended and fixed in $0.5 \mathrm{ml}$ of $1 \%$ formalin in cold PBS, measured using a FACScan flow cytometer (Beckton Dickinson, USA), and analyzed using CELLQuest (ver. 1.2).

All monoclonal antibodies were purchased from Serotec Ltd., and were as follows: hamster anti-mouse TCR $\alpha \beta$ (clone H57-597), mouse anti-mouse NK1.1 antigen (clone PK136), and rat anti-mouse CD3 (clone KT3), CD8 $\alpha$ (clone KT15), TNF $\alpha$ (clone MP6-XT22), CD4 (clone KT174), CD25 (clone PC61.5.3), and CD40 (clone 3/23). 


\section{Spleen Index}

Spleen weights of sacrificed mice were measured and the results were expressed as organ weights per unit body weight, referred to as the spleen index ( $\mathrm{mg} / \mathrm{g}$ body weight).

\section{Statistical Analyses}

All values in this study are presented as mean \pm S.D. The Duncan method and analysis of variance (ANOVA) were used for significance tests and probabilities of less than $5 \%(\mathrm{P}<0.05)$ were considered significant.

\section{Results}

A. blazei hot-water extract inhibited sarcoma 180 (S180) dose-dependently in vivo and in the SRB assay (Table 1). The antitumor effects of A. blazei on S180 are summarized in Fig. 1. Tumor size decreased and the inhibition rate increased with time in all treated groups as compared with the control, and were more

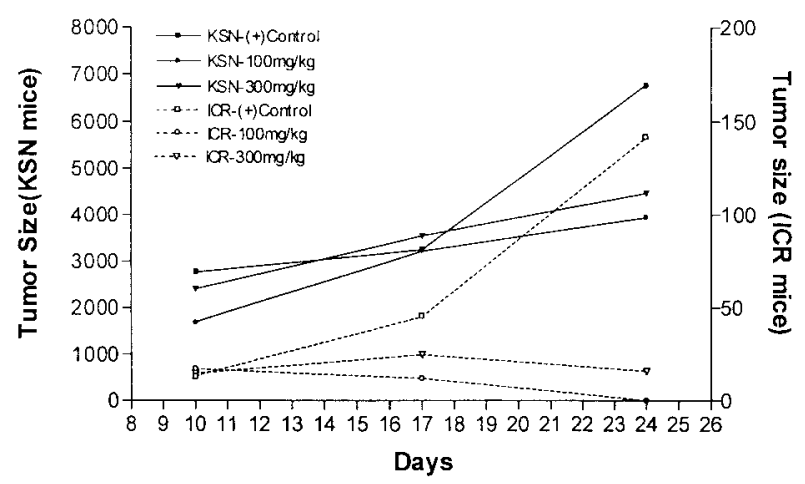

Fig. 1. Change of tumor volume $\left(\mathrm{cm}^{3}\right)$ induced by A. blazei hotwater extract on subcutaneously implanted Sarcoma 180 in ICR and KSN mice ( $\mathrm{n}=6$ /group). evident during the days 17 to 24 . The tumor growth inhibition was much greater in ICR mice than in KSN mice. The tumor size in KSN mice was comparable to the control until day 17. The tumor size in the $100 \mathrm{mg} /$ $\mathrm{kg}$ group of each strain was smaller than that in the 300 $\mathrm{mg} / \mathrm{kg}$ group on day 24 .

In ICR mice, the Spleen index (S.I.) did not increased when compared with normal mice, with the exception of the control group $(1.5196 \pm 1.5529)$. However, all KSN mice showed a significant increase or increasing trend in the S.I. $(\mathrm{P}<0.05)$ (Table 2).

Pan $\mathrm{T}(\mathrm{CD}+)$ cells continuously increased in all treated groups of KSN mice, and activated T cells also increased (Table 3). All values peaked on day 17 in the treated groups and then decreased slightly, but those of the control groups spontaneously increased. The percentage of CD3 and CD25 dual positive cells in all treated groups tended to be higher than those of the controls in both strains. A similar trend was shown in CD4 positive cells, with a peak value in the $100 \mathrm{mg} / \mathrm{kg}$ group of ICR (day17) and KSN (day24) mice. All treated groups of KSN mice showed increased CD8 positive cells, however, in the ICR mice this was not significant. CD3 positive cells and TCR $\alpha / \beta$ receptor positive cells were elevated on Day 17 in the $100 \mathrm{mg} /$ $\mathrm{kg}$ group of ICR mice.

\section{Discussion}

A. blazei inhibited tumor growth via the oral route, and the antitumor effects of the H1 strain were found to increase in the KSN nude mice, similar to Ito's Iwade 101 strain [7]. It is believed that the strain difference of A. blazei may influence the result. It effectively inhibited tumor growths in mice and rats [8]. We administered of A. blazei, in toto, which has not been studied before $[1,2,5]$.

Table 2. Spleen Index (S.I.)

\begin{tabular}{lcccccc}
\hline $\begin{array}{l}\text { Strain } \\
\text { Days }\end{array}$ & 10 & $\begin{array}{c}\text { ICR } \\
17\end{array}$ & 24 & 10 & KSN \\
17 & 24 \\
\hline $\begin{array}{l}\text { (+) Control } \\
100 \mathrm{mg} / \mathrm{kg}\end{array}$ & $0.5104 \pm 0.1743$ & $0.6784 \pm 0.2101$ & $1.5196 \pm 1.5529$ & $0.7221 \pm 0.3096$ & $1.668 \pm 0.5786^{* *}$ & $1.9287 \pm 0.9843^{* *}$ \\
$300 \mathrm{mg} / \mathrm{kg}$ & $0.4551 \pm 0.0950^{*}$ & $0.6575 \pm 0.0548$ & $0.4225 \pm 0.0768$ & $0.7406 \pm 0.2770^{*}$ & $1.8173 \pm 0.4521^{* *}$ & $1.5707 \pm 0.6080^{* *}$ \\
\hline
\end{tabular}

S.I. measured as spleen weight / body weight $(\mathrm{mg} / \mathrm{g})$. Each value is presented as mean \pm S.D. $(\mathrm{n}=6)$. The S.I. of normal mice were as follows: ICR mice, $0.7703 \pm 0.4453, \mathrm{KSN}$ mice $0.3883 \pm 0.0242$. * and $* *$ means $\mathrm{P}<0.05$ and $\mathrm{P}<0.01$ compared with normal mice, respectively. 
Table 3. Effects on splenic CD3, CD4, CD8, CD40, and NKR positive cells after sarcoma 180 inoculation

\begin{tabular}{|c|c|c|c|c|c|c|c|c|}
\hline \multirow[b]{2}{*}{ Treatment } & \multirow[b]{2}{*}{ Day } & \multicolumn{7}{|c|}{ Percentage of positive cells } \\
\hline & & $\begin{array}{c}\text { CD3+ } \\
\text { (Pan T cells) }\end{array}$ & $\mathrm{CD} 3+/ 25+$ & $\begin{array}{c}\text { CD4+ } \\
\text { (Th cells) }\end{array}$ & $\mathrm{CD} 4+/ 8+$ & $\begin{array}{c}\text { CD8+ } \\
\text { (Tc cells) }\end{array}$ & $\begin{array}{l}\text { CD40+ } \\
\text { (B cells) }\end{array}$ & $\mathrm{TCR} \alpha / \beta$ \\
\hline \multicolumn{9}{|l|}{ (ICR mice) } \\
\hline Normal & & $13.23 \pm 5.21$ & & $2.97 \pm 0.52$ & & $8.26 \pm 0.40$ & $16.05 \pm 0.72$ & \\
\hline \multirow{3}{*}{ (+) Control } & 10 & $8.71 \pm 4.84^{\mathrm{a}}$ & $0.52 \pm 0.45^{\mathrm{a}}$ & $11.86 \pm 7.41^{\mathrm{a}}$ & $3.36 \pm 0.55$ & $12.69 \pm 6.50^{\mathrm{a}}$ & $33.25 \pm 22.85^{\mathrm{a}}$ & $0.23 \pm 0.09^{a}$ \\
\hline & 17 & $39.32 \pm 16.76^{\mathrm{a}}$ & $1.96 \pm 0.62$ & $19.29 \pm 8.16^{\mathrm{a}}$ & $6.55 \pm 5.41$ & $20.87 \pm 15.50^{\mathrm{a}}$ & $44.11 \pm 13.19^{a}$ & $1.97 \pm 1.97$ \\
\hline & 24 & $25.74 \pm 14.61^{\mathrm{a}}$ & $1.86 \pm 0.61^{\mathrm{a}}$ & $18.96 \pm 11.80^{\mathrm{a}}$ & $0.87 \pm 0.33$ & $9.08 \pm 2.93^{\mathrm{a}}$ & $43.13 \pm 16.17^{\mathrm{a}}$ & $22.63 \pm 12.68$ \\
\hline \multirow[t]{3}{*}{$100 \mathrm{mg} / \mathrm{kg}$} & 10 & $26.25 \pm 6.45^{b}$ & $1.02 \pm 0.37^{\mathrm{b}}$ & $15.60 \pm 7.96^{\mathrm{a}}$ & $2.66 \pm 0.30$ & $12.22 \pm 3.78^{\mathrm{a}}$ & $52.41 \pm 21.87^{\mathrm{a}}$ & $0.32 \pm 0.14^{\mathrm{a}}$ \\
\hline & 17 & $5.61 \pm 1.99^{b}$ & $2.30 \pm 0.26$ & $28.02 \pm 7.91^{b}$ & $2.88 \pm 3.94$ & $9.83 \pm 4.71^{\mathrm{a}}$ & $49.74 \pm 1.59^{\mathrm{b}}$ & $4.39 \pm 10.52$ \\
\hline & 24 & $33.66 \pm 1.26^{\mathrm{a}}$ & $1.70 \pm 0.35^{\mathrm{ab}}$ & $24.43 \pm 2.10^{\mathrm{b}}$ & $1.04 \pm 0.28$ & $12.04 \pm 1.91^{\mathrm{a}}$ & $55.79 \pm 4.83^{\mathrm{a}}$ & $30.63 \pm 1.96$ \\
\hline \multirow[t]{3}{*}{$300 \mathrm{mg} / \mathrm{kg}$} & 10 & $27.01 \pm 1.36^{\mathrm{c}}$ & $1.60 \pm 0.30^{\mathrm{c}}$ & $19.31 \pm 3.31^{\mathrm{a}}$ & $3.47 \pm 1.13$ & $11.61 \pm 1.15^{\mathrm{b}}$ & $69.42 \pm 4.20^{\mathrm{a}}$ & $0.02 \pm 0.02^{b}$ \\
\hline & 17 & $9.93 \pm 5.81^{b}$ & $1.99 \pm 0.46$ & $22.36 \pm 4.31^{\mathrm{b}}$ & $2.32 \pm 2.28$ & $10.57 \pm 1.98^{b}$ & $52.47 \pm 5.90^{\mathrm{a}}$ & $0.52 \pm 0.61$ \\
\hline & 24 & $6.54 \pm 3.61^{\mathrm{a}}$ & $1.99 \pm 0.42^{\mathrm{b}}$ & $25.93 \pm 4.19^{b}$ & $2.73 \pm 2.50$ & $12.21 \pm 1.35^{\mathrm{a}}$ & $49.54 \pm 3.67 \mathrm{a}$ & $25.20 \pm 3.88$ \\
\hline \multicolumn{9}{|l|}{ (KSN mice) } \\
\hline Normal & & $1.29 \pm 0.43$ & $0.51 \pm 0.09$ & $1.76 \pm 0.26$ & $2.80 \pm 0.20$ & $20.74 \pm 13.52$ & $80.36 \pm 2.27$ & $0.50 \pm 0.18$ \\
\hline \multirow[t]{3}{*}{ (+) Control } & 10 & $0.67 \pm 0.04^{a}$ & $0.35 \pm 0.83^{\mathrm{a}}$ & $2.72 \pm 0.29^{a}$ & $1.60 \pm 0.27 \mathrm{a}$ & $6.73 \pm 0.78^{a}$ & $66.41 \pm 4.07 \mathrm{a}$ & $0.29 \pm 0.10^{\mathrm{a}}$ \\
\hline & 17 & $3.91 \pm 0.75^{\mathrm{a}}$ & $0.24 \pm 0.05$ & $1.03 \pm 0.19^{a}$ & $0.70 \pm 0.19$ & $8.71 \pm 1.92^{\mathrm{a}}$ & $48.20 \pm 3.43^{\mathrm{a}}$ & $0.79 \pm 0.80^{\mathrm{a}}$ \\
\hline & 24 & $8.05 \pm 1.35^{\mathrm{a}}$ & $0.98 \pm 0.22^{\mathrm{a}}$ & $1.19 \pm 0.14^{\mathrm{a}}$ & $2.30 \pm 0.17$ & $19.74 \pm 3.18^{\mathrm{a}}$ & $62.21 \pm 1.26^{\mathrm{a}}$ & $1.04 \pm 0.65$ \\
\hline \multirow[t]{3}{*}{$100 \mathrm{mg} / \mathrm{kg}$} & 10 & $3.35 \pm 0.86^{b}$ & $1.30 \pm 0.46^{\mathrm{b}}$ & $3.69 \pm 1.15^{\mathrm{a}}$ & $4.33 \pm 1.17^{\mathrm{b}}$ & $18.32 \pm 11.94^{\mathrm{a}}$ & $59.24 \pm 5.22^{\mathrm{a}}$ & $1.98 \pm 1.34^{\mathrm{b}}$ \\
\hline & 17 & $3.28 \pm 0.58^{b}$ & $0.21 \pm 0.12$ & $1.01 \pm 0.29^{b}$ & $0.52 \pm 0.08$ & $7.42 \pm 2.51^{\mathrm{a}}$ & $48.24 \pm 5.95^{\mathrm{a}}$ & $1.76 \pm 0.67^{b}$ \\
\hline & 24 & $10.29 \pm 2.07^{a}$ & $2.16 \pm 1.04^{b}$ & $1.41 \pm 0.31^{\mathrm{b}}$ & $2.64 \pm 1.24$ & $18.09 \pm 3.55^{\mathrm{a}}$ & $58.33 \pm 3.10^{\mathrm{a}}$ & $4.49 \pm 1.23$ \\
\hline \multirow[t]{3}{*}{$300 \mathrm{mg} / \mathrm{kg}$} & 10 & $1.46 \pm 0.41^{\mathrm{c}}$ & $1.06 \pm 0.38^{\mathrm{b}}$ & $4.44 \pm 0.76^{\mathrm{a}}$ & $3.61 \pm 0.73^{b}$ & $8.88 \pm 0.41^{\mathrm{b}}$ & $53.49 \pm 3.64^{\mathrm{a}}$ & $1.01 \pm 0.53^{\mathrm{ab}}$ \\
\hline & 17 & $3.51 \pm 0.70^{\mathrm{b}}$ & $0.25 \pm 0.08$ & $1.31 \pm 0.56^{\mathrm{b}}$ & $0.64 \pm 0.37$ & $8.06 \pm 0.41^{\mathrm{b}}$ & $51.18 \pm 3.80^{\mathrm{a}}$ & $0.24 \pm 0.07^{a}$ \\
\hline & 24 & $7.20 \pm 1.53^{\mathrm{a}}$ & $1.52 \pm 0.28^{\mathrm{ab}}$ & $1.13 \pm 0.46^{\mathrm{b}}$ & $1.94 \pm 0.64$ & $15.69 \pm 2.65^{\mathrm{a}}$ & $51.01 \pm 6.88^{a}$ & $4.08 \pm 2.35$ \\
\hline
\end{tabular}

Each value is presented as mean \pm S.D. ( $n=6$ /group). N/T means 'not tested'. abc different superscripts in the same column differ significantly at $\alpha=0.05$ level by Duncan's multiple test.

It has been suggested that polysaccharides from edible mushrooms are to involved in the activation of various immunocompetent cells such as macrophages, neutrophils, T cells and NK cells [3, 12]. NK cells are one of the first to act in terms of immunological response, and are widely distributed in nude mice. A significant NK cell increase was shown after A. blazei, administration. Thus, we believe that the cancer inhibition effect had a similar tendency in the ICR and KSN mice during the first 7 days. Furthermore, the increase in the relative spleen weight (Table 2) indicates that A. blazei acted upon the immunological cells. A. blazei showed antitumor effects on ICR mice in vitro and in vivo. A per oral administration case in Swiss/ NIH mice was reported by Ito et al.[7] using the S180 inoculation model. However, the present study showed higher cancer growth inhibition with the same cell line. In the present study the $\mathrm{H} 1$ strain was tested in toto rather than as functional substances, and showed an antitumor effect by oral administration similar to that shown in humans. We believe there is a need to examine the extract components to determine the cause of the effect.

The cancer inhibition rate decreased in KSN mice with time, even though an increase in $\mathrm{T}$ cell was shown by both ICR and KSN mice. The immunocyte increase rate in KSN was higher than that in ICR mice, therefore quantitative and serial immunological responses may play a role in cancer inhibition. The mechanism of antitumor effects by polysaccharides has been attributed to the potentiation of the host-defense through cellular immunity $[4,11]$. Therefore, $T$ cells can be shown to act upon cancers due to A. blazei and other polysaccharides, however, other immunological cells were also augmented and systemically inhibited S180. Even though nude mice have long been used for general tumor inoculation studies due to their genetic immunodeficiency, KSN nude mice do not provide a proper means for discriminating between the active immunological cellular subset or the tumor inhibition 
mechanism by A. blazei. Therefore, it may be worthwhile to perform studies using other immunodeficient animals, such as those that are $\mathrm{B}$ and $\mathrm{T}$ cell deficient.

In conclusion, it is proposed that A. blazei (H1 strain) hot-water extract may show antitumor effects by stimulating immunocytes because it contains functional substances. Even though it could not totally inhibit tumor cell growth in vitro, it showed anticancer effects in vivo. It showed different efficacies in S180 models between strains $[1,3,4,7,11]$. Therefore, to determine the antitumor effect of A. blazei or other polysaccharides in natural products, it is thought that a tumor inoculation model would be more useful than an in vitro study. However, we need to know which substance in A. blazei inhibits the cells. Moreover, a more detailed study of its specificity to organs or species may be valuable in terms of clarifying its mode of action, and we suggest that its antitumor effectiveness be studied in different organs.

\section{Acknowledgments}

This research was supported by the Hallym Academy of Sci Hallym University, Korea (2000-5-2).

\section{References}

1. Osaki, Y., Kato, T., Yamamoto, K., Okubo, J., and Miyazaki, T. 1994. Antimutagenic and bactericidal substances in the fruit body of a Basidiomycete Agaricus blazei, Jun-17 Yakugaku Zasshi. 114:342-350.

2. Ito, H., Hidaka, H., and Sugiura, M. 1979. Effects of coriolan, an antitumor polysaccharide, produced by Coriolus versicolor Iwade. Jpn. J. Pharmacol. 29: 953-957.

3. Ebina, T. and Fujimiya, Y. 1998. Antitumor effect of a peptide-glucan preparation extracted from Agaricus blazei in a double-grafted tumor system in mice. Biotherapy 11 : 259-265.
4. Itoh, H., Ito, H., Amano, H., and Noda, H. 1994. Inhibitory action of a (1-->6)-beta-D-glucan-protein complex (F III2-b) isolated from Agaricus blazei Murill ("himematsutake") on Meth A fibrosarcoma-bearing mice and its antitumor mechanism. Jpn. J. Pharmacol. 66: 265-271.

5. Fujimiya, Y., Suzuki, Y., Oshiman, K., Kobori, H., Moriguchi, K., Nakashima, H., Matumoto, Y., Takahara, S., Ebina, T., and Katakura, R. 1998. Selective tumoricidal effect of soluble proteoglucan extracted from the basidiomycete, Agaricus blazei Murill, mediated via natural killer cell activation and apoptosis. Cancer Immunol. Immunother. 46: 147-159.

6. Fujimiya, Y., Suzuki, Y., Katakura, R., and Ebina, T. 1999. Tumor-specific cytocidal and immunopotentiating effects of relatively low molecular weight products derived from the basidiomycete, Agaricus blazei Murill. Anticancer Res. 19: $113-118$.

7. Ito, H., Shimura, K., Itoh, H., and Kawade, M. 1997. Antitumor effects of a new polysaccharide-protein complex (ATOM) prepared from Agaricus blazei (Iwade strain 101) "Himematsutake" and its mechanisms in tumor-bearing mice. Anticancer Res. 17: 277-284.

8. Higaki, M., Eguchi, F., and Watanabe, Y. 1997. A stable culturing method and pharmacological effects of the Agaricus blazei. Nippon Yakurigaku Zasshi. 110 (Suppl 1): $98 \mathrm{P}-103 \mathrm{P}$

9. Kawagishi, H., Nomura, A., Yumen, T., Mizuno, T., Hagiwara, T., and Nakamura, T. 1998. Isolation and properties of a lectin from the fruiting bodies of Agaricus blazei. Carbohydr Res. 183: 150-154.

10. Rosen, S., Bergstrom, J., Karlsson, K.A., and Tunlid, A. 1996. A multispecific saline-soluble lectin from the parasitic fungus Arthrobotrys oligospora. Similarities in the binding specificities compared with a lectin from the mushroom Agaricus bisporus. Eur. J. Biochem. 238: 830-837.

11. Kawagishi, H., Inagaki, R., Kanao, T., Mizuno, T., Shimura, K., Ito, H., Hagiwara, T., and Nakamura, T. 1989. Fractionation and antitumor activity of the water-insoluble residue of Agaricus blazei fruiting bodies. Carbohydr Res. 186: $267-273$.

12. Mizuno, M., Morimoto, M., Minato, K., and Tsuchida, H. 1996. Polysaccharides from Agaricus blazei stimulate lymphocyte T-cell subsets in mice. Biosci. Biotechnol. Biochem. 62: 434-437. 